are issued by the Survey for the more important Atlantic harbours, as well as for the Pacific coast of Canada. The tides are complicated by a great variation in range, and the observations secured will serve also as a basis for future investigation of the currents, many of the strongest of them being tidal in their nature.

\section{THE ABSORPTION SPECTRA OF SALINE} SOLUTIONS.

IN the Scientific Transactions of the Royal Dublin Society (vol. vii. series ii. pp. 253-312), Prof. W. N. IIartley gives the results of a long series of experimental investigations which he has undertaken to determine the action of heat on the absorption spectra and chemical constitution of saline solutions. After reviewing previous researches by Schœnbein, von Babo, Schiff, Gladstone, Bunsen, Melde, Burger, Vogel, Landauer, Morton, Bolton and Russell, the author gives a description of his mode of experimenting. Wedge-shaped cells containing the liquids under examination were heated in an air-bath with glass sides. The sources of light used were sunlight and an argand burner fed with oxygen.

Then the absorption spectra of solutions of the salts of nickel, copper, cobalt, chromium, uranium, didymium, and various permanganates are described, with details of the measurements, accompanied by drawings from, or reproductions of, the photographed spectra. Much of the discussion is directed to the bearing of the spectral evidence as to the constitution of the solutions, and the following conclusions indicate the results arrived at :-

(I) The absorption spectra of different salts of the same metal, whether solid or in solution, are not identical, even when the spectrum is a marked characteristic of the metal.

(2) When a definite crystalline hydrate dissolves in a solvent which is not water, and is not a dehydrating agent, the molecule of the salt remains intact.

(3) In any series of salts which are anhydrous, and which do not form well-defined crystalline hydrates, the action of heat up to the temperature of $100^{\circ} \mathrm{C}$. does not cause any further alteration in their absorption spectra beyond that which is usual with substances which undergo no chemical change by such rise of temperature. The change is usually an increase in the intensity of the absorption, or a slight widening of the absorption bands.

(4) As a rule the crystallised metallic salts, in which water is an integral part of the molecule, dissolve in water at ordinary temperatures without dissociation of the molecule.

(5) Crystallised hydrated salts, dissolved in a minimum of water at $20^{\circ} \mathrm{C}$., undergo dissociation by rise of temperature. The extent of the dissociation may proceed as far as complete dehydration of the compound, so that more or less of the anhydrous salt may be formed in the solution.

(6) The ninst stable compound which can exist in a saturated solution at $16^{\circ}$ or $20^{\circ} \mathrm{C}$. is not always of the same composition as the crystalline solid at the same temperature, since the solid may undergo partial dissociation from its water of crystallisation when the molecule enters into solution.

(7) Saturated solutions of hygroscopic and deliquescent salts combine with water when diluted to constiiute molecules of more complex hydrated compounds in solution.

(8) When a saturated solution of a coloured salt undergoes a great change of colour upon dilution, or any remarkable change in its absorption spectrum due to the same cause, the dilution is always accompanied by considerable evolution of heat.

\section{CONFERENCE OF SCIENCE MASTERS IN PUBLIC SCHOOLS.}

WHILE carrying out the important work of spreading scientific instruction in this country, our educationists should make themselves quite sure that the teaching already inaugurated is what it claims to be. Care must be exercised in order that a training in habits of exactness and observation is imparted, as well as an appreciation of the principles of science quite apart from a mere knowledge of facts. By intelligent practical work upon the part of the individual scholar this alone can le attained, and under present circumstances such exercise is difficult to successfully organise in schools.

Expensive laboratories and able masters are of no avail if the

No. I 630 , vOL. 637 necessary conditions be not introduced. The scientific staffs of our large public schools are fully aware of their responsibility to the nation, and what is lacking to enable them to fulfil it. It might, therefore, be thought that they would have been the very first to advocate the necessary changes, but their position, it will be seen, is such a peculiar one that, without strong general feeling behind them, their trouble would be all thrown away.

With the dawn of the new century, however, and in view of the present agitation for an improved system of scientific education, the public school science masters have combined all their energies for the attainment of that end. On January 19 , therefore, a conference was held at the rooms of the University of London, and was attended by a thoroughly representative body of men. Sir Henry Roscoe, Vice-Chancellor of the University, and a member of the governing body of Eton College, occupied the chair, and explained the importance of the action taken.

Among the papers read, that by Mr. Oswald $H$. Latter, of Charterhouse, contained perhaps the most general observations. "Science teaching," he tuld us, "was first introduced into our public schools as a sop to a growing public opinion, and with a desire to impart a gentjemanly acquaintance with scientific matters. The broad-minded persons who ventured on this new departure imagined, unfortunately, that the admirable mediaval methods of classical and mathematical teaching were equally well suited to the new comer, who, however, had to be content with a very small portion of the temporal possessions of its elder bretheren." Mr. Latter then urged the necessity of a scientific education for future legislators, and our commercial and professional men, and from a national point of view. Form teaching would do much, he considered, to remove the incubus of ignorance and apathy in the coming generation, the following being his recommendations with regard to it:-

(I) Science should be raised to the dignity of a "form subject," and no lunger be regarded as a more or less negligeable extra. It should enter for at least one hour into the ordinary work of every day, and claim, at any rate, some portion of the time devoted to preparation. There must be some lopping of the old branches of education if good fruit is to be borne by the engrafted scion.

(2) A classification according to proficiency in science throughout the school.

(3) At least half, and with lower forms more than half, of the allotted hours should be devoted to systematic laboratory work in the elements of physics and chemistry.

(4) The teaching should be continued to the sixth forms instead of being deliberately withheld from them as is so often the case, a distinction which at once narrows the intellectual horizon of the ablest boys in the school, and degrades the subject in the eyes of the remainder.

Mr. E. E. Ashford, of Harrow, would with very good reason teach some physics before chemistry, and, if possible, element. ary biology before either, for, he said, let us first use the facts a boy knows to teach the methods of science. All boys, he continued, are acquainted with many bits of natural history, and its general laws were more easily appreciated than the more exact ones of the other sciences. The paper by Mr. Ashford concluded with the following resolution, which found favour with the meeting, viz., that "it is essential that every bny before leaving school should go through a course of practical measurement and experiment involving no previous theoretical knowledge."

Prof. Armstrong, who was present, true to his tenets that academic words should not be used in schools, suggested nature-study in place of biology, but the terms were not recog nised as synonymous by several speakers, and so he was somewhat misunderstood. Mr. A. Vassall, in describing the work at Inarrow, recommended that the biological lessons should form a continuous course, and it must be remembered that the boys (over fourteen and under sixteen years of age) he teaches are not tiny children for whom unconnected object-lessons are best adapted. The list of lessons given to the conference well illustrated Mr. Vassall's plea for the "judicious skipping" of subjects not quite suitable for introductory work. Mr. Cumming, of Rugby, used, he said, to teach all his boys botany; he owned, however, that he had no qualifications but a love of the subject, and it is not surprising that the other sciences he has since substituted have succeeded better.

Mr. W. D. Eggar, of Eton, pointed out that, nwing to ex. ternal pressure, many public schools had started elementary 
physical measurements for small boys, following Board School methods; but that in the latter institutions mathematical and science teaching were continuous, the same master teaching both to the same boys. In public schools the two subjects are kept separate. Much of what is now taught in the laboratory could more usefully be acquired in mathematical class-rooms with all the necessary apparatus. Mathematics would gain enormously, and much valuable science time be saved. Here Mr. Eggar submitted that he was only urging the adoption of practical mathematics which Prof. Perry had long advocated, and without opposition, but also without any visible effect upon the universities, which still, among other things, demanded a modicum of unapplied and undigested algebra. Sir Henry Roscoe bore out what Mr. Eggar had said, and proposed that a meeting of mathematical masters should be held, at which Prof. P'erry might possibly convince them. Speaking as a mathematical master, Mr. Hurst, of Fton, cordially agreed with the views of Prof. Perry. and Mr. Eggar; he stated, however, that limited time and the requirements of the universities utterly forbade their adoption in his own case. Another point emphasised by Mr. Eggar was that trigonometry mechanics should be introduced at an earlier stage into the teaching of mathematics, and his resolution that "some knowledge of physics should be required of all candidates for a university degree," was carried unanimously.

The universities came in also for a grood deal of criticism, among other examining bodies, from Mr. C. Falkner, of Weymouth. Their entrance science scholarships cause boys to specialise while too young, and before they have got a sound foundation upon which to base their education. No college seems to require the same scope of science, and this necessitates what amounts to the private coaching of every boy in the scholarship class of a public schrol. Mr. Falkner had some very good suggestions to make for the improvement of these and army examinations, and repeated the plea that is now finding much favour, that teachers and examiners should meet and work together.

The paper by Mr. W. II. Lewis, of Fxeter, was not discussed, owing to the author's absence. It dealt with the desirability of longer hours and smaller classes, and larger staffs. The difficulty which a "literary" head-master has of realising the peculiarly laborious nature of scicnce teaching where complicated apparatus has to be fitted up was also alluded to.

An inceresting survey of the work of school natural history societies was to be found in the address by Mr. A. Vassall, of Harrow, and the discussion upon it. Many advantages were claimed for the subjects involved, from the education of future landowners and travellers as well as for the boys at school. The sectional system, which divides workers up into groups according to their study, was advocated. Compulsory games very often spoiled matters, and inuividualism, Mr. Vassall very rightly pronounced, was thereby extinguished. Public opinion among the boys and the standing aloof of those with influence, as well as the apathy of many masters, were also cited as obstacles in the way of field work at schools. Nevertheless, quite a number of successful societies at present exist.

Many suggestive methods of actually dividing up the time for teaching were given by various members of the conference; but, one takes it, the most useful purpose it will serve is to bring before head-masters, governors of schools, and examining bodies the results of the experience and the serious recommend ations of a body of picked scientific men whose hearts are in their work.

$$
\text { WIIFRFII MARK WEBH. }
$$

\section{UNIVERSITY AND EDUCATIONAL INTELLIGENCE.}

THE annual meeting of the Association of Technical Institutions will be held on Tuesday, January 29 , in the Fishmongers' Hall, London. An address will be given by Sir W. Hart Dyke, Bart., M.P.

Wr learn from Science that Dr. I). K. Pearsons has given Colorado College 50,000 dollars, promised some time since, and it is reported that he has given Northwestern University 30,000 dollars for the erection of a woman's dormitory, and 200,000 dollars to an educational institution, the name of which is not to be made public during his life time. It is believed that Dr. Pearsons' gifts to educational institutions amount to three million dollars.

$$
\text { No. } \left.16_{3} \text {. VOL. } 6_{3}\right]
$$

\section{SCIENTIFIC SERIAL.}

THE Journai of Botany for January contains a useful paper by Mr. Arthur Lister on the cultivation of the Mycetozoa from spores. Mr. George Murray and Mr. C. Bucknall contriluute a discussion on the question whether the box, Fuxus sempervirens, is a native of Britain. They conclude that this is unquestionably the case with the locality near Wootton-under-Edge, an adjacent farm having been known as "Boxwell" for at least seven centuries. This increases the probability of the shrub being indigenous also in other localities, including Boxhill, near Dorking. Mr. W. Carruthers and Miss A. Lorrain Smith have a paper on a disease in turnips caused by bacteria. Prof. Potter has named the bacterium Psitu:lomonas destructans.

\section{SOCIETIES AND ACADEMIES. \\ LoNDoN.}

Geological Society, lanuary 9.-J. J. II. Teall, F.R.S., President, in the chair. - The geology of South-Central Ceylon, by John Parkinson. In this communication the author endea. vours to give some account of the relations between the various granulitic rocks of Ceylon. A series of more or less isolated sections were studied, the rocks in each considered under separate heads, and conclusions put forward relative to the whole. - Note on the occurrence of corundum as a contact. mineral at Pont-Paul, near Morlaix (Finistère), by A. K. Coomára-Swámy. The intrusive granite of Pont-P'aul, near Morlaix, contains highly altered fragments of sedimentary rock. The minerals found in them are biotite, muscovite, corundum (first recorded by Prof. Barrois in 1887 ), plagioclase, andalusite, pyrite, magnetite, sillimanite, green spinel, and zircon.

Mathematical Society, January Io.-Dr. IIobson, F.R.S., President, in the chair.-Prof. Love, F.R.S., made a communication on streaming motions past cylindrical boundaries. Mr. Basset, F.R.S., also spoke on the subject.Mr. Campbell read a paper entitled "A Pron of the Third Fundamental Theorem in Liè's Theory of Continuous (iroups." - The President communicated a paper by Mr. L. IV. Barnes on the zeroes of Bessel's functions, and a paper on some cases of the solution of $z^{p}{ }^{n}-1 \equiv \mathrm{I}$, mod. $p$, by Prof. F. S. Carey.

Zoological Society, January 15.-Prof. G. B. Howes, F.R.S., Vice-President, in the chair.-Mr. IV. E. de IVinton exhibited and made remarks on a skin of the large grey Cynictis (Cy'nictis selousi), obtained by Mr. P. C. Reid on the west bank of the Iinyanti River, South Africa. The species had been described from a skull only, from Bulawayo, and the skin of the animal had previously been unknown to naturalisıs. Mr. O. Thomas exhibited, on behalf of Mr. R. Lydekker, a specimen of the skull of a common fox (Canis vulpes) with two upper canines on each side of the jaw. - In describing the collecticn of fishes brought home from Lakes Tanganyika and Kivu by the Tanganyika Exploring Expedition, under the leadership of MIr. J. E. S. Moore, Mr. (i. A. Boulenger pointed out that the study of this important collection did not modify the conclusions embodied in his first report published in 1898 . The exploration of Lake Kivu had thrown no light on the origin of the Tangranyikan fauna; the smaller lake proved to be very thinly populated with fishes, which all belonged to widely distributed genera, the species showing a mixture of Nile and Tanganyika elements, with two that might prove to be endemic. The list of the fishes from the two lakes comprised 91 species, 74 of which had been named by the author. The collection now described consisted of examples of 50 species, 26 of which were new to science, 2 being made the types of additional genera of the family Cichlidae.-Mr. G. A. Boulenger read a paper on a collection of freshwater fishes made by Dr. W. J. Ansorge in the Niger Delta. The collection was described as one of exceptional interest. One of the two new genera, for which the name Phractolaemus ansorgii was proposed, consti. tuted the type of a new family (Phractolxemidx), intermediate between the Osteoglossidx and the Clupeidx. The second new genus, Polycentropsis, belonged to the Nandidx, a family new to Africa ; its position was regarded as near the South American Poly'centrus. A new Gnathonemus and three new Pelmatochromis were also described. -A communication was read from 